\title{
Some Miocene cheilostome bryozoan genera of Michel Vigneaux - systematic revision and scanning electron microscopic study
}

Emanuela DI MARTINO

Paul D. TAYLOR

Department of Earth Sciences, Natural History Museum, Cromwell Road, SW7 5BD, London (United Kingdom)

e.di-martino@nhm.ac.uk

Published on 29 December 2017

KEY WORDS

Nomenclature, fossil,

Miocene,

Neogene,

Aquitaine Basin, lectotypification, new combinations, new synonyms.

MOTS CLÉS

Nomenclature,
fossile,

fossile,

Néogène,

Bassin Aquitain, lectotypification, combinaisons nouvelles, synonymes nouveaux.
Di Martino E. \& Taylor P. D. 2017. - Some Miocene cheilostome bryozoan genera of Michel Vigneaux - systematic revision and scanning electron microscopic study. Geodiversitas 39 (4): 783-796. https://doi.org/10.5252/g2017n4a7

\section{ABSTRACT}

In 1949 Michel Vigneaux published an important taxonomic work on fossil bryozoans that introduced numerous new taxa at family-, genus- and species-levels, the majority of which are still used today, in some cases for extant bryozoans. However, Vigneaux's material from the Miocene of the Aquitaine Basin in France has never been revised. Here we employ scanning electron microscopy (SEM) to study Vigneaux's type specimens of the type species of five of his genera: Hemiphylactella, Pleuromucrum, Stephanollina, Schizosmittina and Hemicosciniopsis. Based on this revision, Pleuromucrum is considered to be a subjective senior synonym of both Lifuella Gordon \& d'Hondt, 1997 and Allorhynchozoon Liu in Liu, Yin \& Ma, 2001.

\section{RÉSUMÉ}

Les genres de bryozoaires cheilostomes de Michel Vigneaux - révision systématique et étude au microscope électronique à balayage.

En 1949 Michel Vigneaux a publié un important travail sur les bryozoaires fossiles, introduisant de nombreux nouveaux taxons au niveau de la famille, du genre et de l'espèce. La majorité d'entre eux sont encore utilisés aujourd'hui, quelque fois pour des bryozoaires récents. Toutefois, le materiel de Vigneaux, provenant du Miocène du Bassin d'Aquitaine en France, n’a jamais été revisé. Dans ce travail nous avons utilisé la microscopie electronique à balayage (MEB) pour étudier les espèces-types de cinq genres: Hemiphylactella, Pleuromucrum, Stephanollina, Schizosmittina et Hemicosciniopsis. Sur la base de cette révision, Pleuromucrum est consideré comme synonyme de Lifuella Gordon \& d'Hondt, 1997 et Allorhynchozoon Liu in Liu, Yin \& Ma, 2001; étant le plus ancien il doit être utilisé en priorité. 


\section{INTRODUCTION}

A major work on bryozoans by Michel Vigneaux, entitled 'Révision des Bryozoaires Néogènes du Bassin d'Aquitaine et essai de classification', was published in 1949. The author's aim was to develop a new classification, mainly for fossil cheilostome bryozoans, based on skeletal characters significantly related to the biology and physiology of the zooid, though without any pretence of completeness. Vigneaux's study was based on Neogene bryozoans from the Aquitaine Basin of southwest France, which are today housed in the collections of the University of Bordeaux, and those of J. Duvergier and F. Canu, as well as additional material collected by several researchers from the Faculty of Sciences at the University of Bordeaux. This work introduced 36 new family-rank and 18 new genus-rank taxa, and 60 new species. Of these, 14 families, 14 genera and 57 species are still considered as valid, although some of the new species have since been transferred to different genera.

Despite the importance of the material described by $\mathrm{Vi}$ gneaux (1949), it has yet to be restudied. A recent visit to the micropalaeontological collections of the University of Bordeaux allowed study of the critical type specimens of the type species of some of the new Miocene genera introduced by Vigneaux. The aim of this paper is to illustrate these specimens, some for the first time, using scanning electron microscopy (SEM) and to give revised diagnoses for the genera. This research leads to a re-evaluation of Vigneaux's little-known genera, some of which have been neglected because they were poorly illustrated when first published, as it is the case for Pleuromucrum Vigneaux, 1949, which is here considered as a subjective senior synonym of Lifuella Gordon \& d'Hondt, 1997. In addition, this work will provide useful information for the revision of the cheilostome volume of the 'Treatise on Invertebrate Paleontology' currently in progress.

\section{MATERIAL AND METHODS}

The type specimens of the type species belonging to five cheilostome bryozoan genera introduced by Vigneaux (1949) were studied, namely Hemiphylactella (H. pulchra), Pleuromucrum (P. saucatsense), Stephanollina (S. multidentata), Schizosmittina (S. planovicellata) and Hemicosciniopsis (H. incrustans). Additionally, the type specimens of two other species of Hemiphylactella (H.? crassovicellata and H.? latebrosa) were studied. All of this material is housed in the micropalaeontological collection of the 'Unité de Formation et Recherche Sciences de la Terre et de la Mer' at the University of Bordeaux, France. Those genera introduced by Vigneaux (1949), but for which the descriptions were based on type species and specimens introduced by other authors (e.g., J. Duvergier, J. V. Audouin, F. Canu, and A. M. Norman), are not considered in this study. For comparison with Pleuromucrum saucatsense, the lectotype (NHMUK 1906.12.3.4) and syntype (NHMUK 1975.7.28.24) of the Recent species Lifuella multidentata (Thornely, 1905) from Ceylon, as well as two syntypes (NHMUK 1999. 3.9.7) of Lifuella articulata (Philipps, 1900) from Lifu, Loyalty Island, were studied.
Scanning electron microscopy (SEM) was conducted on uncoated specimens using a low-vacuum scanning electron microscope (LEO VP-1455) at the NHMUK. Zooidal measurements were taken from SEM images of the type specimens using the image-processing program ImageJ. Each measurement is given in the text as the mean value \pm the standard deviation, observed range, and total number of measurements made (the latter value enclosed in parentheses).

\section{ABBREVIATIONS \\ Measurements \\ AvL avicularium length; \\ $\mathrm{AvW}$ avicularium width; \\ OL orifice length; \\ OW orifice width; \\ OvL ovicell length; \\ OvW ovicell width; \\ ZL autozooid length; \\ ZW autozooid width.}

\section{SYSTEMATIC PALAEONTOLOGY}

Family ROMANCHEINIDAE Jullien, 1888

Genus Hemiphylactella Vigneaux, 1949

TYPE SPECIES. - Hemiphylactella pulchra Vigneaux, 1949 by original designation.

EMENDED DIAGNOSIS. - Colony encrusting, multiserial, unilaminar, with zooids arranged quincuncially. Zooids with convex frontal shield, tubercular or smooth, imperforate apart from a single row of marginal areolar pores. Primary orifice with a straight, convex or concave proximal margin and small condyles, surrounded by a flared to tubular peristome; oral spines present or absent. Ovicells hyperstomial, small, globular. Avicularia absent. Pore-chamber windows present or absent.

\section{REMARKS}

In addition to the Burdigalian type species, Hemiphylactella pulchra (Fig. 1; see description below), two Serravallian species were included by Vigneaux (1949) in this genus: H.? crassovicellata (Fig. 2; see description below) and H.? latebrosa (Fig. 3; see description below), both from Salles, Gironde.

Hemiphylactella is similar to the smittinid Phylactella Hincks, 1879 in having a deep flaring peristome, but differs in having oral spines, an imperforate frontal shield and ovicell, and in lacking a lyrula. Among other genera included in Romancheinidae, Escharella Gray, 1848 is the most similar, differing from Hemiphylactella most conspicuously in having a large lyrula.

Hemiphylactella pulchra Vigneaux, 1949 (Fig. 1)

Material EXAmineD. — Figured syntype (Vigneaux 1949: 84, pl. 8, fig. 1), C.B.398. This specimen is here designated as the lectotype of the species.

Type LOCALrTY. — Moulin de P'Eglise, Saucats, Gironde, Aquitaine, France.

AgE. — Burdigalian, early Miocene. 

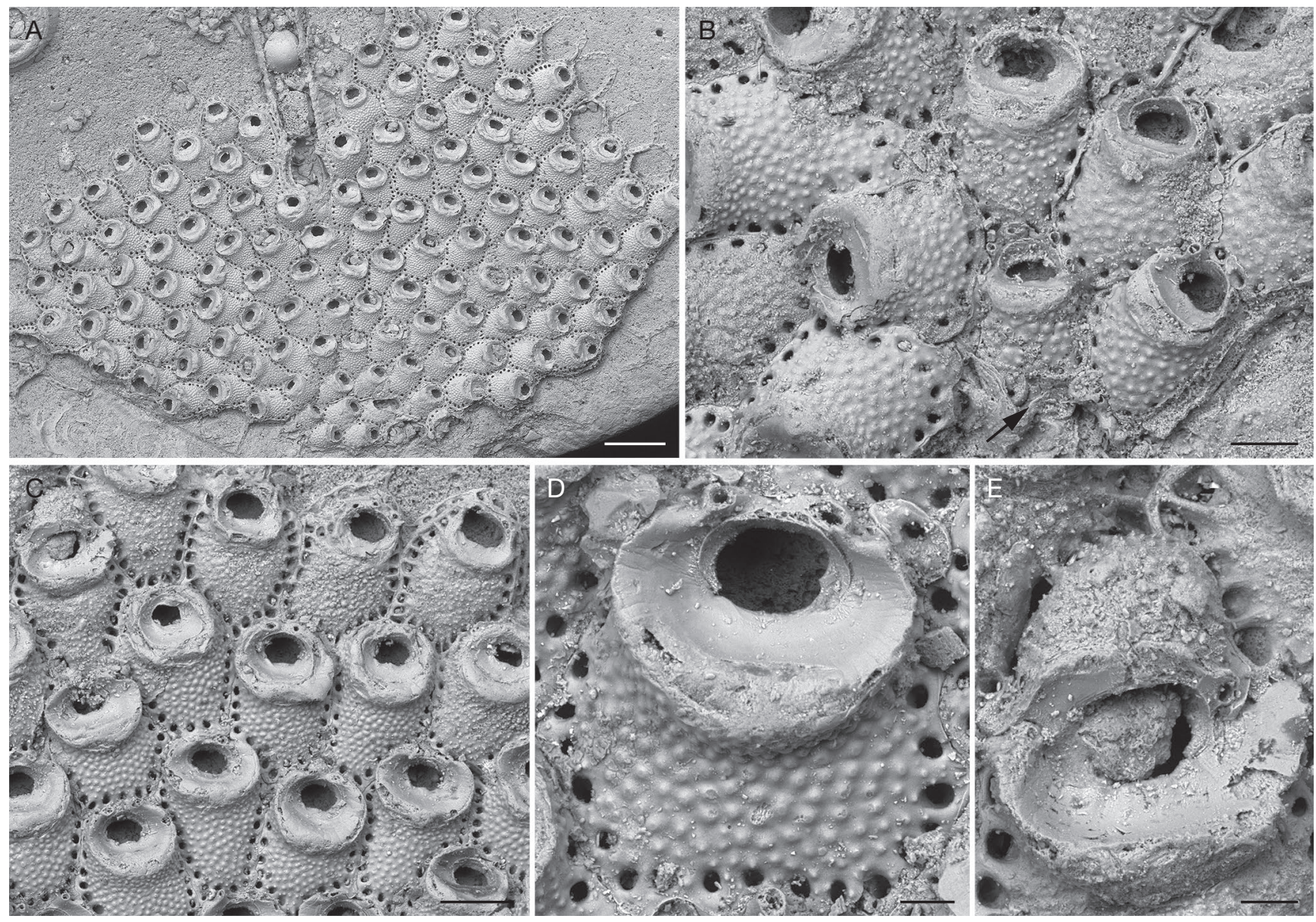

FlG. 1. - Hemiphylactella pulchra Vigneaux, 1949, figured syntype C.B.398, Burdigalian, early Miocene, Moulin de l'Église, Saucats, Gironde, Aquitaine, France: A, general view of the colony; B, ?first budded zooid (see arrow) and early astogeny; C, group of autozooids with a single ovicellate zooid; D, close-up of an autozooid; E, close-up of the ooecium. Scale bars: A, $500 \mu \mathrm{m} ; \mathrm{B}, 100 \mu \mathrm{m} ; \mathrm{C}, 200 \mu \mathrm{m} ; \mathrm{D}, \mathrm{E}, 50 \mu \mathrm{m}$.

\section{DESCRIPTION}

Colony encrusting, multiserial, unilaminar (Fig. 1A). Ancestrula unknown; astogenetically oldest preserved zooid, probably the first budded autozooid (Fig. 1B, see arrow), similar to later autozooids but smaller, about $245 \mu \mathrm{m}$ long by $180 \mu \mathrm{m}$ wide, and bearing four oral spine bases. Zooids arranged quincuncially, distinct, boundaries marked by very narrow furrows, hexagonal, longer than wide (mean $\mathrm{L} / \mathrm{W}=$ 1.24). Frontal shield slightly convex, tubercular, imperforate except for a single row of marginal areolar pores, on average 18 per zooid, oval to circular, $15-25 \mu \mathrm{m}$ in diameter (Fig. 1C). Orifice placed distally, broader than long, the proximal rim slightly convex or straight and with two tiny condyles placed proximally to the mid-lateral position (Fig. 1D). A smooth, flared peristome, more developed proximally and laterally than distally, surrounds the orifice, embedding generally two, rarely three (Fig. 1C), distal, largely spaced oral spine bases, 25-35 $\mu \mathrm{m}$ in diameter. Ovicells hyperstomial. Ooecium small, about $95 \mu \mathrm{m}$ long by $165 \mu \mathrm{m}$ wide, globular, cap-like, with a finer granulation than the frontal shield (Fig. 1E); the proximal rim of the ooecium is covered by the smooth upturned peristome. At least one oral spine base is still visible in ovicellate zooids (Fig. 1E). Avicularia absent. Numerous, oval pore-chamber windows visible at colony growing edge along the distolateral zooidal margin, $25-40 \mu \mathrm{m}$ long by $10-$ $15 \mu \mathrm{m}$ wide (Fig. 1C).

\section{MEASUREMENTS}

ZL $416 \pm 25,365-470$ (20); ZW $337 \pm 26,277-389$ (20); OL $64 \pm 6,48-75(20)$; OW $94 \pm 4,87-103(20)$.

\section{REMARKS}

Several differences occur between Hemiphylactella pulchra and the two congeneric species, such as the presence/absence of oral spine bases and pore-chamber windows (see below).

\section{Hemiphylactella? crassovicellata Vigneaux, 1949}

(Fig. 2)

Material EXamined. — Figured syntype (Vigneaux 1949: 85, pl. 8, fig. 2), C.B.450. This specimen is here designated as the lectotype of the species.

TYPE LOCALiTY. — Salles, Gironde, Aquitaine, France.

AgE. — Serravallian, middle Miocene. 

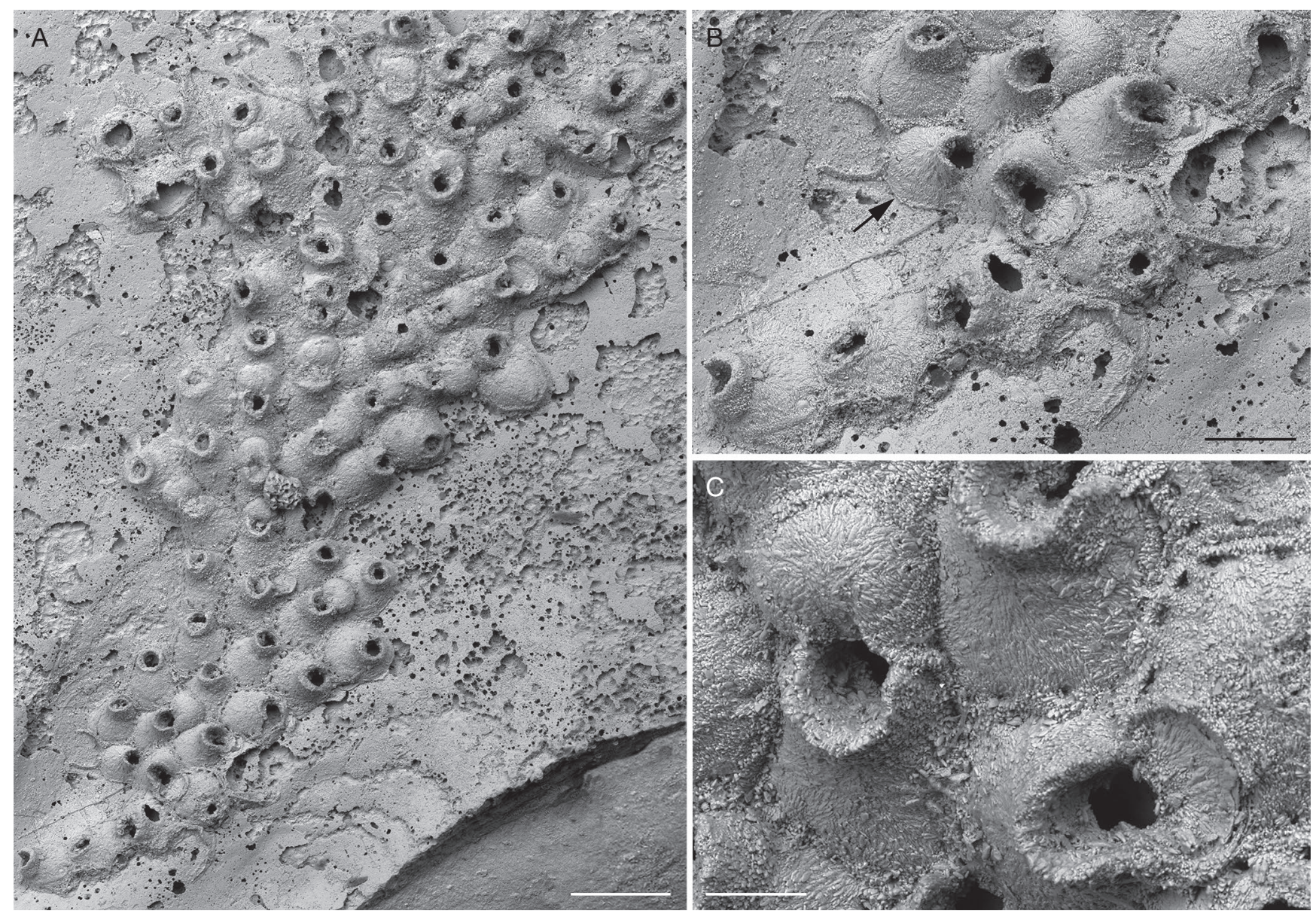

FIG. 2. - Hemiphylactella? crassovicellata Vigneaux, 1949, figured syntype C.B.450, Serravallian, middle Miocene, Salles, Gironde, Aquitaine, France: A, general view of the colony; B, ?ancestrula and early astogeny; C, close-up of an ovicellate zooid and autozooid showing the cleithridiate orifice. Scale bars: A, 500 mm; B, $200 \mu \mathrm{m}$; C, $100 \mu \mathrm{m}$.

\section{DESCRIPTION}

Colony encrusting, oligoserial to multiserial, fan-shaped, unilaminar (Fig. 2A). Putative ancestrula similar to later autozooids but smaller, about $215 \mu \mathrm{m}$ long by $190 \mu \mathrm{m}$ wide, budding four zooids arranged in a semicircle (Fig. 2B). Later zooids arranged quincuncially, distinct, boundaries marked by raised ridges, rounded polygonal, slightly longer than broad (mean $\mathrm{L} / \mathrm{W}=1.18$ ). Frontal shield slightly convex, apparently finely granular, imperforate except for a sometime visible single row of marginal areolar pores, on average 10 per zooid, oval to circular, 10-25 $\mu \mathrm{m}$ in diameter (Fig. 2B, C). Orifice placed distally, almost equidimensional, about $65 \mu \mathrm{m}$ long by $60 \mu \mathrm{m}$ wide, key-hole shaped (cleithridiate), with the proximal rim straight and two tiny condyles placed proximally to the mid-lateral position (Fig. 2C). A smooth, tubular peristome, more developed and slightly flared proximally, surrounds the orifice (Fig. 2C); oral spine bases absent. Ovicells hyperstomial. Ooecium broader than long, globular to elliptical, apparently finely granular like the frontal shield (Fig. 2B, C). Avicularia absent. Oval pore-chamber windows not observed.
MEASUREMENTS

ZL $364 \pm 38$, 308-432 (20); ZW 309 \pm 38, 229-386 (20); OvL $148 \pm 12,132-183$ (16); OvW $205 \pm 8,190-219$ (16).

\section{REMARKS}

The figured syntype specimen of Hemiphylactella? crassovicellata is a small colony encrusting a shell fragment. The specimen is poorly preserved. Severe recrystallization prevents the observation of the marginal areolar pores in the majority of the zooids, the orifice is often obliterated by cement or sediment, while porechamber windows seem genuinely absent. The epitaxial calcite cement on the surfaces of the zooids hinders clear observation of the texture of the frontal shield, which is interpreted here as finely granular. Hemiphylactella? crassovicellata differs from $H$. pulchra in the lack of oral spine bases and pore-chamber windows, in having a much larger ooecium, which is not cap-like, a smaller key-hole shaped orifice surrounded by a less flared peristome, and an apparently finer granulation of the frontal shield. If our interpretation of the ancestrula is correct, this would imply very early sexual maturity in the colony as ovicells are present in the first generation of budded zooids. 

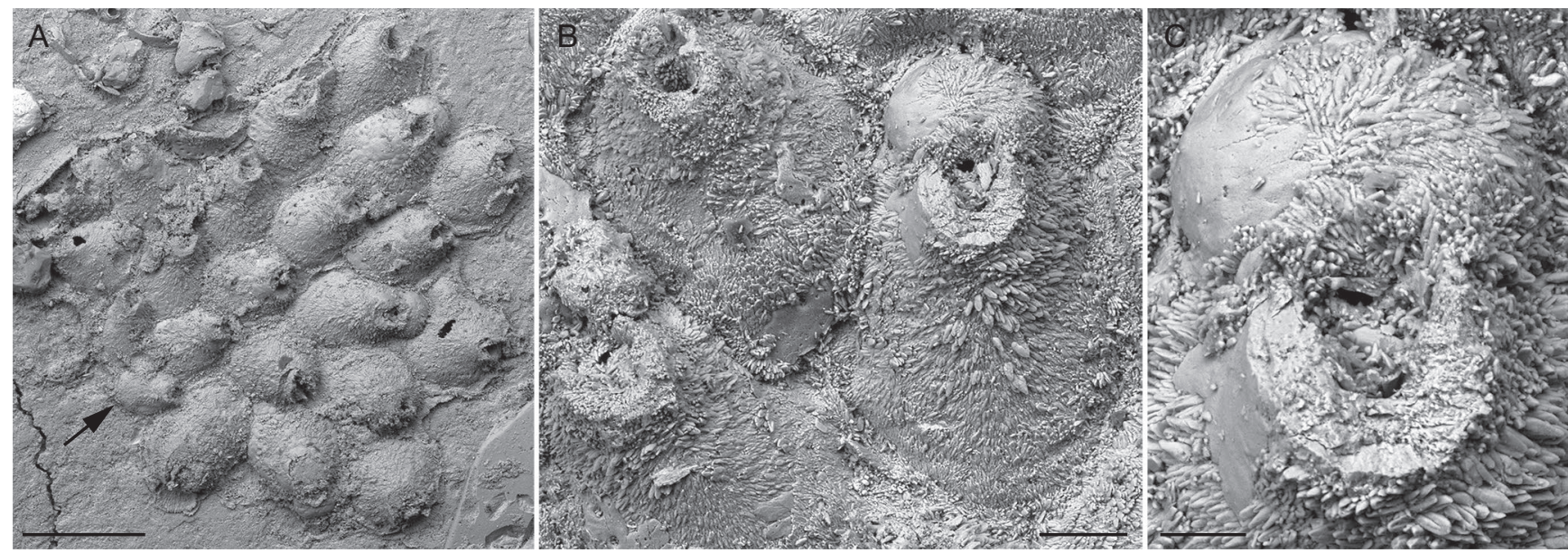

FIG. 3. - Hemiphylactella? latebrosa Vigneaux, 1949, figured syntype C.B.451, Serravallian, middle Miocene, Salles, Gironde, Aquitaine, France: A, general view of the colony with ?ancestrula (see arrow) and early astogeny; B, close-up of an ovicellate zooid and autozooid; note the smooth frontal shield and frontal surface of the ooecium where not affected by recrystallization. Marginal areolar pores are visible in the bottom left corner; $\mathbf{C}$, close-up of the ooecium and ?cleithridiate orifice. Scale bars: A, $500 \mu \mathrm{m} ; \mathrm{B}, 100 \mu \mathrm{m} ; \mathrm{C}, 50 \mu \mathrm{m}$.

\section{Hemiphylactella? latebrosa Vigneaux, 1949}

(Fig. 3)

MATERIAL EXAMined. — Figured syntype (Vigneaux 1949: 85, pl. 8, fig. 3), C.B.451. This specimen is here designated as the lectotype of the species.

Type Locality. - Salles, Gironde, Aquitaine, France.

AGE. - Serravallian, middle Miocene.

\section{DESCRIPTION}

Colony encrusting, multiserial, unilaminar (Fig. 3A). Putative ancestrula similar to later autozooids but smaller, about $280 \mu \mathrm{m}$ long by $180 \mu \mathrm{m}$ wide, budding two zooids laterally (Fig. 3A). Later zooids arranged quincuncially, distinct, boundaries marked by narrow furrows, rounded polygonal, longer than broad (mean $\mathrm{L} / \mathrm{W}=1.26$ ). Frontal shield slightly convex, smooth, imperforate except for an occasionally visible single row of marginal areolar pores, transversely oval to circular, 15-20 $\mu \mathrm{m}$ long (Fig. 3A, B). Orifice placed distally, longer than broad, about $120 \mu \mathrm{m}$ long by $95 \mu \mathrm{m}$ wide, seemingly key-hole shaped (cleithridiate) with a concave proximal edge (Fig. 3C). A slightly raised, tubular peristome surrounds the orifice proximally and laterally (Fig. 3C); oral spine bases absent. Ovicells hyperstomial. Ooecium broader than long, globular, cap-like, smooth like the frontal shield (Fig. 3B, C). Avicularia absent. Pore-chamber windows not observed.

\section{MEASUREMENTS}

ZL $453 \pm 33$, 412-504 (10); ZW $360 \pm 24$, 306-399 (10); OvL $73 \pm 10,65-84$ (3); OvW $189 \pm 10,178-198$ (3).

\section{REMARKS}

Hemiphylactella? latebrosa differs from $H$. pulchra, the type species of the genus, in lacking oral spine bases and porechamber windows, for which reason we assign this species only tentatively to Hemiphylactella. Furthermore, H.? latebrosa has a smooth frontal shield while in $H$. pulchra the frontal shield is coarsely granular. The two species possess ovicells of similar shape and size, whereas the ovicell in H.? crassovicellata is much larger than in the other two species. Hemiphylactella? crassovicellata also has a finely granular frontal shield

\section{Family SFENIELLIDAE Gordon, 2006}

EMENDED DIAGNOSIS. - Colony encrusting, planar. Autozooids with marginal areolar pores, with or without sparse pseudopores penetrating the frontal shield. Secondary orifice cormidial, defined by surrounding frontal shields. Oral spines present. Avicularia and zooidal polymorphs present or absent. Ovicells prominent.

\section{Genus Stephanollina Vigneaux, 1949}

TyPe SPECIES. - Stephanollona (Stephanollina) dentata Vigneaux, 1949 by original designation.

EMENDED DIAGNOSIS. - Colony encrusting. Zooids with ill-defined boundaries. Frontal shield nodular, imperforate apart from sparse marginal areolar pores. Primary orifice with a shallow sinus; secondary orifice cormidial with lobes and cusps. Oral spines present. Avicularia adventitious, budded from marginal areolar pores. Ovicell globular.

\section{REMARKS}

Stephanollina was introduced by Vigneaux (1949) as a subgenus of Stephanollona Duvergier. Gordon (2006) ruled out any relationship between Stephanollina and Stephanollona, suggesting elevation of Stephanollina to genus rank and tentatively including it in the family Sfeniellidae. However, the diagnosis of the family Sfeniellidae is based solely on Sfeniella and must be modified to include Stephanollina (see above). The latter genus lacks the sparse pseudopores penetrating the frontal shield and the polymorphs resembling autozooids but with reduced orifices that are typical of Sfeniella, while avicularia are present. Stephanollina shares with Sfeniella a cormidial secondary orifice 
and the presence of oral spine bases. The diagnostic features of Stephanollina were observed also in 'Gemelliporella' vorax Canu \& Bassler, 1923 sensu Gordon (2006: pl. 2, figs 3, 4), which is here considered as congeneric, although limited to the specimens re-examined by Gordon (2006) from the Miocene of North Carolina. Other specimens figured in Canu \& Bassler (1923: pl. 19, figs 1-9) seem to belong to different genera.

\section{Stephanollina dentata Vigneaux, 1949}

(Fig. 4)

MATERial EXAMINED. - Figured syntype (Vigneaux 1949: 80, pl. 7, fig. 13), C.B.429-1. This specimen is here designated as the lectotype of the species.

Type Locality. - Manciet, Gers, Aquitaine, France.

AGE. — Langhian, middle Miocene.

\section{DESCRIPTION}

Colony encrusting, multiserial, unilaminar (Fig. 4A). Zooids quincuncially arranged with ill-defined boundaries, sometimes marked by marginal areolar pores or narrow, shallow furrows (Fig. 4A, B). Frontal shield slightly convex or flat, nodular, imperforate apart from sparse, circular to elliptical, marginal areolar pores, 15-30 $\mu \mathrm{m}$ long (Fig. 4B). Primary orifice somewhat rounded, almost equidimensional, with two small condyles proximally placed separating an arched anter from a very shallow, slightly narrower sinus with a faintly concave proximal margin (Fig. 4C, D). Secondary orifice cormidial, formed by the frontal shield of the three surrounding distal zooids, forming a crenulated margin of lobes and cusps, the latter in the position of the oral spines (Fig. 4C, D). A suboral mucro rarely developed (Fig. 4A, see arrow). Five distal oral spine bases, the proximalmost pair generally larger, about $20 \mu \mathrm{m}$ in diameter, while the others are about $10 \mu \mathrm{m}$ in diameter (Fig. 4C, D). Adventitious avicularia budded from marginal areolar pores, often latero-oral, elliptical, without condyles or pivotal bar (Fig. 4B, C). No complete ovicells observed; incomplete ovicells with ooecium longer than broad, resting on the frontal shield of the next distal zooid or pair of zooids (Fig. 4A, B).

\section{MEASUREMENTS}

ZL $275 \pm 20,247-329$ (15); ZW $223 \pm 26,186-276$ (15); OL $76 \pm$ 4, 71-82 (10); OW $86 \pm 1,84-88$ (10); OvL $103 \pm 6$, 96-113 (5); OvW $150 \pm$ 14, 127-162 (5); AvL $63 \pm$ 6, 53-71 (10); AvW $49 \pm 6,40-57$ (10).

\section{REMARKS}

Stephanollina dentata is very similar in appearance to the specimen of Stephanollina vorax (Canu \& Bassler, 1923) n. comb. figured by Gordon (2006: pl. 2, figs 3, 4), the two species differing mainly in the number of oral spine bases (five in S. dentata, four in $S$. vorax n. comb.), and in the shape of the orificial sinus, which is deeper and more markedly concave in $S$. vorax n. comb. Ovicells and avicularian chambers are generally broken or incomplete in both species.

\section{Family BiteCTIPORIDAe MacGillivray, 1895}

\section{Genus Schizosmittina Vigneaux, 1949}

TYPE SPECIES. - Schizosmittina planovicellata Vigneaux, 1949 by original designation.

EMENDED DIAGNOSIS. - Colony encrusting with zooids arranged in alternating parallel rows or bilamellar. Frontal shield evenly pseudoporous with distinct marginal areolar pores. Orifice sinuate with distinct condyles, often corrugated; lyrula absent; oral spines evanescent, present on marginal zooids only. Avicularia present or absent, adventitious or vicarious, when adventitious often suboral and associated with the peristome. Ovicells with a peripheral band of rugose calcification and a broad, flat, pseudoporous frontal area. Basal pore-chamber windows or mural septula present.

\section{REMARKS}

The genus Schizosmittina was resurrected by Gordon (1984) and subsequently recorded in both fossil and Recent material from a wide geographical area. Gordon (1994) noted that he had examined Vigneaux's type material of $S$. planovicellata, scanning a few isolated zooids and using this information to rediagnose the genus. The earliest occurrence is Schizosmittina ovicellata Zágoršek \& Kázmér, 2001 from the Priabonian (late Eocene) of Hungary, followed by the Rupelian (early Oligocene) S. bathydonta (Brown, 1952) from New Zealand. Among extant species, four (S. bicornis, S. cinctipora, $S$. conjuncta, $S$. melanobater) are currently known from New Zealand waters (Gordon 1984, 1989), two (S. maplestonei and S. vitrea) from Australia (MacGillivray 1879), one (S. lizzya) from South Africa (Florence et al. 2007), and one (S. pedicellata) from the eastern Pacific off USA coast (Soule et al. 1995).

\section{Schizosmittina planovicellata Vigneaux, 1949}

(Fig. 5)

MATERIAL EXAMINED. - Figured syntype (Vigneaux 1949: 104, pl. 10, fig. 5), C.B.510-1. This specimen is here designated as the lectotype of the species.

Type Locality. - Salles, Gironde, Aquitaine, France.

AGE. - Serravallian, middle Miocene.

\section{DESCRIPTION}

Colony encrusting, multiserial, unilaminar (Fig. 5A). Zooids arranged in parallel rows, distinct by deep furrows, subrectangular, twice as long as wide (mean L/W $=2.05$ ). Frontal shield slightly convex, nodular, evenly pseudoporous; pseudopores circular, large, about $20 \mu \mathrm{m}$ in diameter (Fig. 5A, B). Marginal areolar pores distinct, larger than pseudopores, about $35 \mu \mathrm{m}$ in diameter (Fig. $5 \mathrm{~A}$, $\mathrm{B}, \mathrm{D})$. Orifice longer than wide, about $100 \mu \mathrm{m}$ long by $70 \mu \mathrm{m}$ wide, with a narrow, deep U-shaped sinus and two, rectangular, corrugated condyles (Fig. 5C); oral spines absent. A raised peristome, more developed proximally and laterally, hides the primary orifice, and encloses a small, oval 

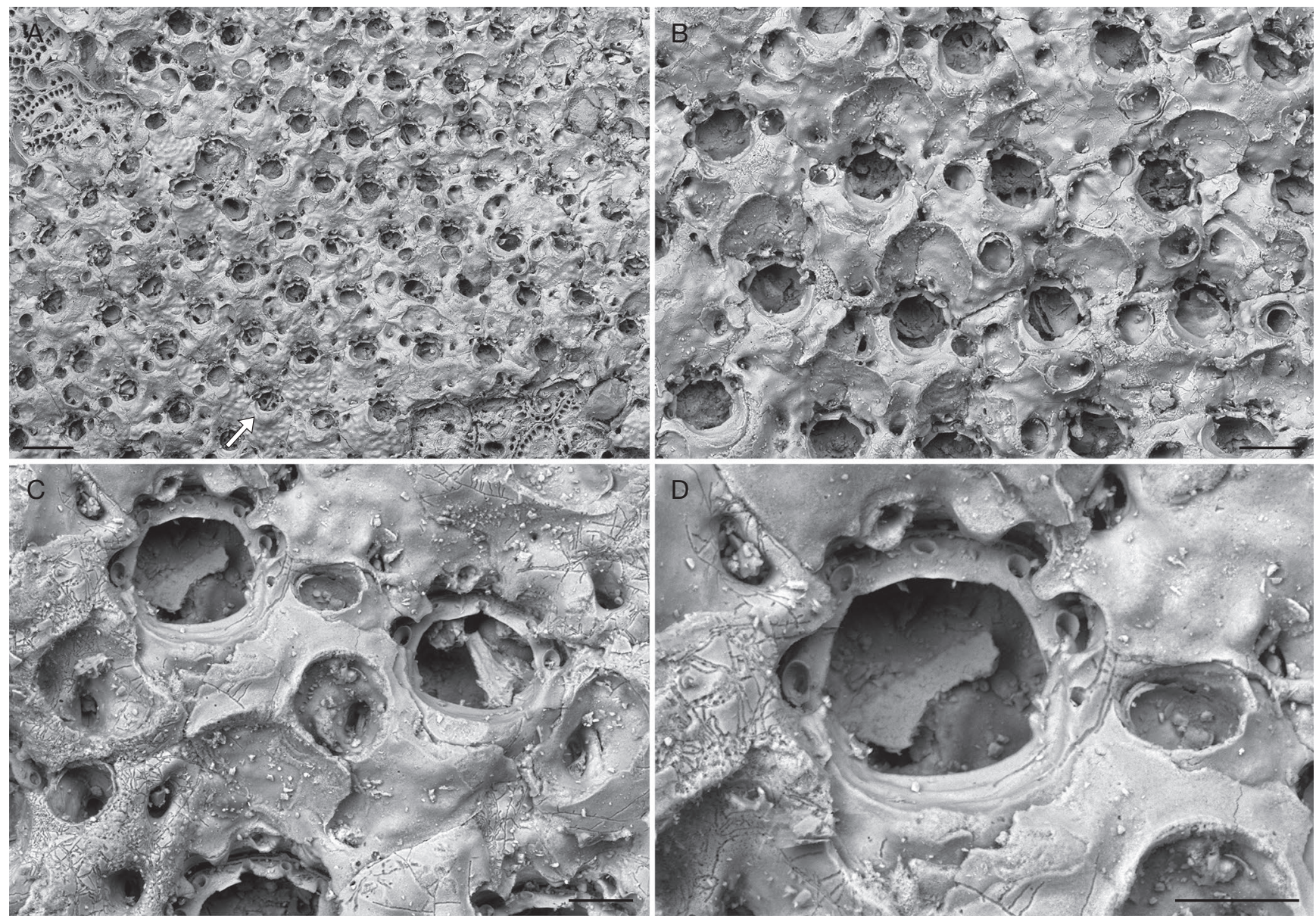

FIG. 4. - Stephanollina dentata Vigneaux, 1949, figured syntype C.B.429-1, Langhian, middle Miocene, Manciet, Gers, Aquitaine, France: A, general view of the colony; the arrow shows an autozooid with developed suboral mucro; $\mathbf{B}$, group of zooids with incomplete ovicells and broken avicularian chambers; C, close-up of two autozooids with elliptical avicularia; $\mathbf{D}$, close-up of the primary orifice showing five oral spine bases and the cormidial secondary orifice with alternating lobes and cusps. Scale bars: A, $200 \mu \mathrm{m} ; \mathrm{B}, 100 \mu \mathrm{m} ; \mathrm{C}, \mathrm{D}, 50 \mu \mathrm{m}$.

suboral avicularium sloping inwardly, proximally directed and with a complete crossbar (Fig. 5D). Vicarious avicularia absent. Ovicells large, globular, pseudoporous covered by a band of rugose calcification continuous with the frontal shield of the next distal zooid (Fig. 5A, B, D). Basal porechamber windows visible along distolateral zooidal margins at the colony growing edge, elliptical, about $15 \mu \mathrm{m}$ long by $10 \mu \mathrm{m}$ wide (Fig. 5E).

\section{MEASUREMENTS}

ZL $478 \pm 25$, 452-519 (10); ZW $234 \pm 22,204-271$ (10); OvL $149 \pm 10,136-167$ (10); OvW $186 \pm 13,167-203$ (10).

REMARKS

Schizosmittina planovicellata differs from the fossil congeneric species, S. ovicellata and S. bathydonta, in having an encrusting rather than an erect colony-form. Recent species also differ: S. maplestonei (MacGillivray, 1879) has a pair of frontal tubercles proximal to the orifice; $S$. vitrea (MacGillivray, 1879), S. conjuncta (Uttley \& Bullivant, 1972) and S. melanobater Gordon, 1989 have a much broader, widely rounded sinus; S. cinctipora (Hincks, 1883) has large adventitious avicularia on the frontal shield; S. bicornis Gordon, 1989 is distinguished by a pair of prominences present on either side of the orifice; $S$. lizzya Florence, Hayward \& Gibbons, 2007 has a subimmersed tripartite ovicell with a single, almost medial foramen. The five, stout oral spines present in S. pedicellata Soule, Soule \& Chaney, 1995 link this species more with Schizomavella rather than Schizosmittina.

Family Gigantoporidae Bassler, 1935

Genus Hemicosciniopsis Vigneaux, 1949

TYPE SPECIES. - Hemicosciniopsis incrustans Vigneaux, 1949 by original designation.

EMENDED DIAGNOSIS. — Colony encrusting with zooids irregularly arranged. Frontal shield evenly pseudoporous. Orifice dimorphic: cleithridiate in non-ovicellate autozooids, bell-shaped with a broader sinus in ovicellate zooids. Oral spines absent. Avicularia suboral with complete crossbar. Ovicells bulbous with pseudopores and calcification resembling the frontal shield. 

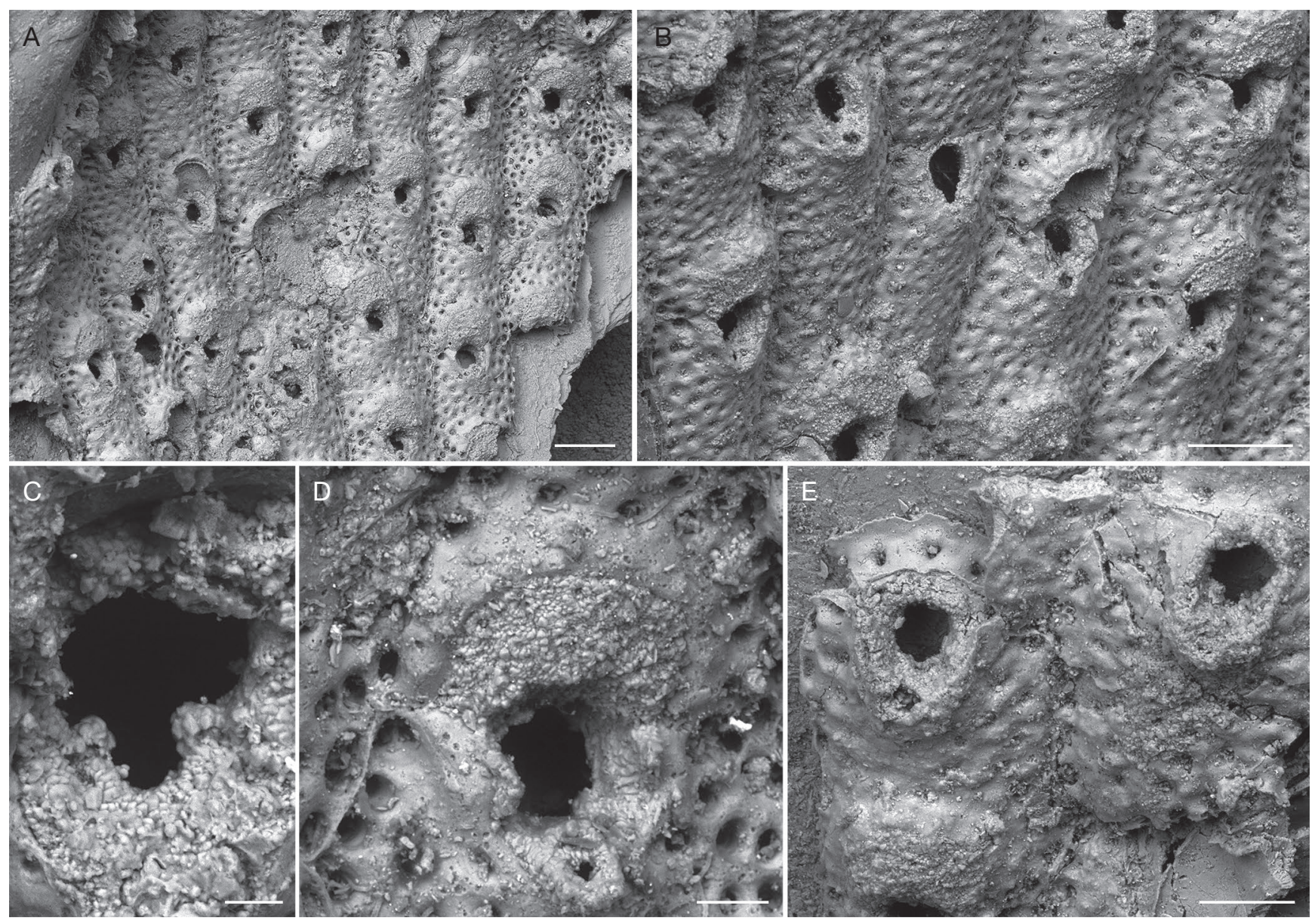

FIG. 5. - Schizosmittina planovicellata Vigneaux, 1949, figured syntype C.B.510-1, Serravallian, middle Miocene, Salles, Gironde, Aquitaine, France. A, group of ovicellate autozooids; B, close-up of autozooids and ovicellate zooids; C, close-up of the orifice showing the deep, narrow sinus and the corrugated condyles; D, close-up of an ovicell and suboral avicularium with complete crossbar; E, close-up of two autozooids at the colony growing edge showing basal pore-chamber windows. Scale bars: A, B, $200 \mu \mathrm{m} ; \mathrm{C}, 20 \mu \mathrm{m} ; \mathrm{D}, 50 \mu \mathrm{m} ; \mathrm{E}, 100 \mu \mathrm{m}$.

\section{REMARKS}

Vigneaux (1949) introduced the genus Hemicosciniopsis for Cosciniopsis-like species with differently shaped orifice in nonovicellate and ovicellate (maternal) autozooids. Based on Tilbrook's (2006: 236) revised diagnosis of Cosciniopsis, Hemicosciniopsis differs also in having avicularia. However, although the type species of Cosciniopsis, C. coelatus Canu \& Bassler, 1927, lacks avicularia, other species assigned to the genus, such as the wellknown C. lonchaea (Busk, 1884), have latero-oral avicularia.

\section{Hemicosciniopsis incrustans Vigneaux, 1949} (Fig. 6)

MATERIAl EXAMined. - Figured syntype (Vigneaux 1949: 76, pl. 7, fig. 6), C.B.97-1. This specimen is here designated as the lectotype of the species.

Type locality. - Pessac, Lorient, Gironde, Aquitaine, France.

AGE. - Aquitanian, early Miocene.

\section{DESCRIPTION}

Colony encrusting, uniserial, multilaminar (Fig. 6A). Zooids irregularly arranged, separated by more or less marked furrows, irregularly polygonal, longer than wide (mean L/W $=1.25$ ). Frontal shield convex, nodular and evenly pseudoporous (Fig. 6B, C); pseudopores circular, large, $15-25 \mu \mathrm{m}$ in diameter, arranged quincuncially, on average 30 per zooid. Orifice dimorphic: cleithridiate in non-ovicellate autozooids with two small, rounded condyles medially directed, separating an arched anter from a smaller bowl-shaped sinus, about $150 \mu \mathrm{m}$ long by $130 \mu \mathrm{m}$ wide (Fig. 6D); bell-shaped and slightly larger in ovicellate zooids, about $180 \mu \mathrm{m}$ long by $150 \mu \mathrm{m}$ wide, with two robust condyles downwards directed separating an arched anter from a larger, shallow poster (Fig. 6E). Depending on the degree of calcification, in some zooids the orifice may be completely or partially obliterated (Fig. 6B, F). Sometimes a smooth, imperforate, peristomial ridge surrounds the orifice proximally, enclosing a small, elliptical, adventitious avicularium, proximolaterally directed and with complete crossbar (Fig. 6F). Ovicells bulbous resting on the frontal shield of the next distal zooid, calcification pseudoporous and resembling a frontal shield (Fig. 6B, C, E).

\section{MEASUREMENTS}

ZL $512 \pm$ 46, 457-593 (12); ZW $408 \pm$ 37, 330-451 (12); OvL $208 \pm$ 6, 200-215 (5); OvW $279 \pm$ 18, 265-303 (5); AvL $65 \pm$ 9, 53-74 (5); AvW $43 \pm 5$, 34-47 (5). 

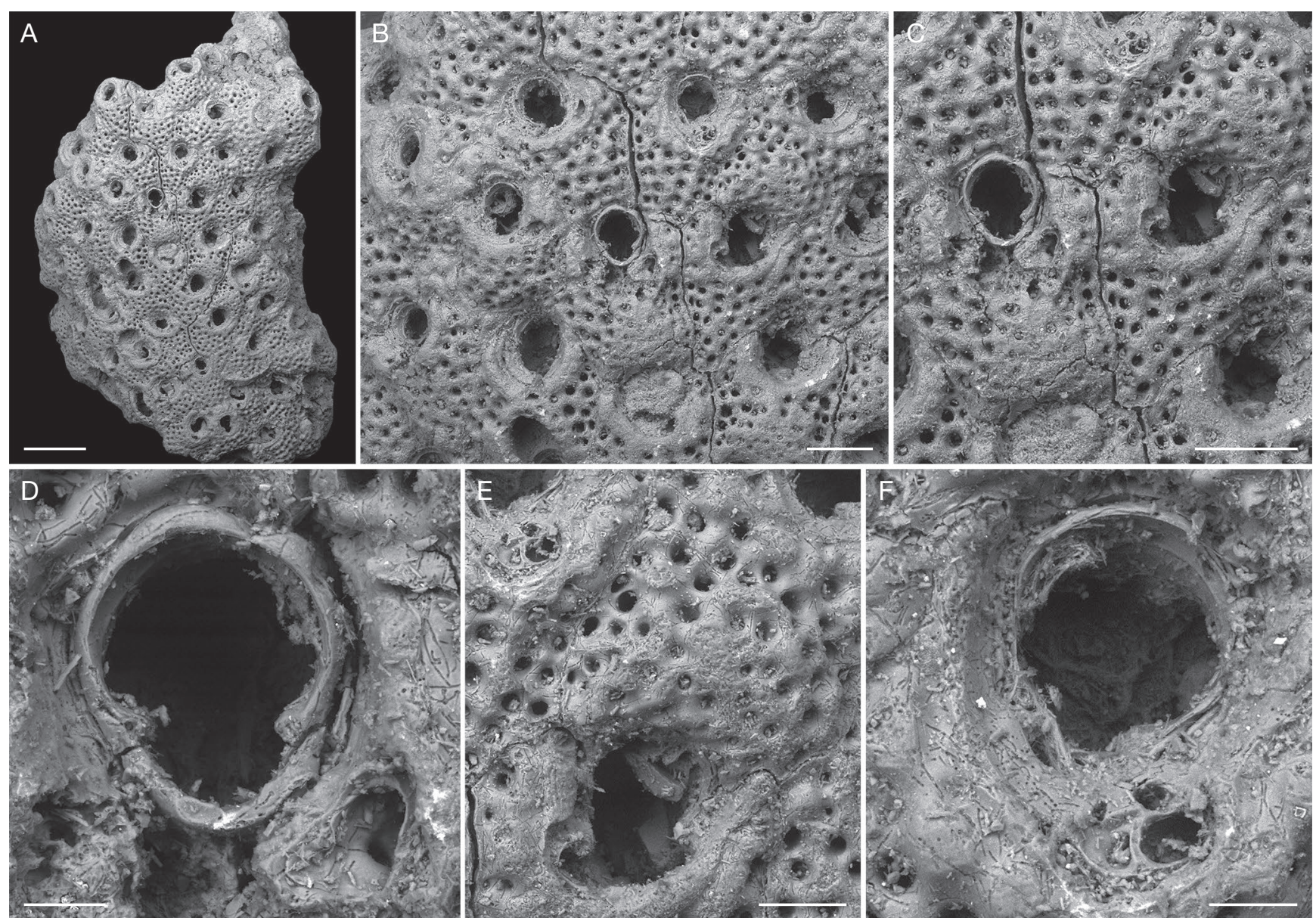

FIG. 6. - Hemicosciniopsis incrustans Vigneaux, 1949, figured syntype C.B.97-1, Aquitanian, early Miocene, Pessac, Lorient, Gironde, Aquitaine, France. A, general view of the colony; $\mathbf{B}$, group of ovicellate and non-ovicellate zooids; C, close-up of an autozooid and ovicellate zooid showing dimorphic orifices; $\mathbf{D}$, close-up of an autozooid orifice with suboral avicularium; $\mathbf{E}$, close-up of the ovicell and orifice of a maternal zooid; $\mathbf{F}$, close-up of a suboral avicularium showing complete crossbar. Scale bars: A, $500 \mu \mathrm{m} ; \mathrm{B}, \mathrm{C}, 200 \mu \mathrm{m} ; \mathrm{D}, \mathrm{F}, 50 \mu \mathrm{m} ; \mathrm{E}, 100 \mu \mathrm{m}$.

\section{REMARKS}

The two small fragments of Hemicosciniopsis incrustans available for study are likely to have encrusted an ephemeral substrate, such as an alga or seagrass, based on the hollow, cylindrical colony-form.

Family Phidoloporidae Gabb \& Horn, 1862

$$
\text { Genus Pleuromucrum Vigneaux, } 1949
$$

Lifuella Gordon \& d'Hondt, 1997: 21, n. syn.

Allorhynchozoon Liu in Liu, Yin \& Ma, 2001: 821, n. syn.

Type sPeCIEs. - Pleuromucrum saucatsense Vigneaux, 1949 by original designation.

EMENDED DIAGNOSIS. - Colony encrusting. Zooids with convex frontal shield, nodular, imperforate apart from occasionally sparse marginal areolar pores. Primary orifice bell-shaped, with a broadly arcuate, smooth-rimmed anter and more or less developed condyles. Oral spines present in both fertile and infertile zooids. A suboral mucro often developed. Adventitious avicularia, when present, triangular and latero-oral or sparse on the frontal shield, budded from marginal areolar pores. Ovicells subimmersed, globular, with a widely arched opening.
REMARKS

Since its introduction by Vigneaux (1949) the genus Pleuromucrum has been largely overlooked, although Cheetham (1963: 73) placed it in synonymy with Pleurolyrula Vigneaux, 1949. However, Pleurolyrula as the name suggests possesses a lyrula which is absent in Pleuromucrum. Examination of the type species of Lifuella Gordon \& d'Hondt, 1997, Lepralia multidentata Thornely, 1905 (Fig. 7), and the type species of Pleuromucrum, P. saucatsense Vigneaux, 1949 (Fig. 9), allowed us to ascertain the close similarity between these two genera, and consequently Lifuella is here considered as a junior subjective synonym of Pleuromucrum.

Gordon \& d'Hondt (1997: 58) introduced Lifuella for Lepralia calyciformis Philipps, 1900, as well as all of the tropical and warm-temperate species previously attributed to Hippoporella Canu, 1917, which seemingly had little in common with the boreal-arctic type species of Hippoporella, $H$. hippopus (Smitt, 1868), including the type species of Lifuella, L. multidentata (Thornely, 1905). Subsequently, Tilbrook et al. (2001: 95) assigned Lifuella calyciformis to the new genus, Fodinella Tilbrook, Hayward \& Gordon, 2001, which differs from Lifuella in having a beaded anter. 

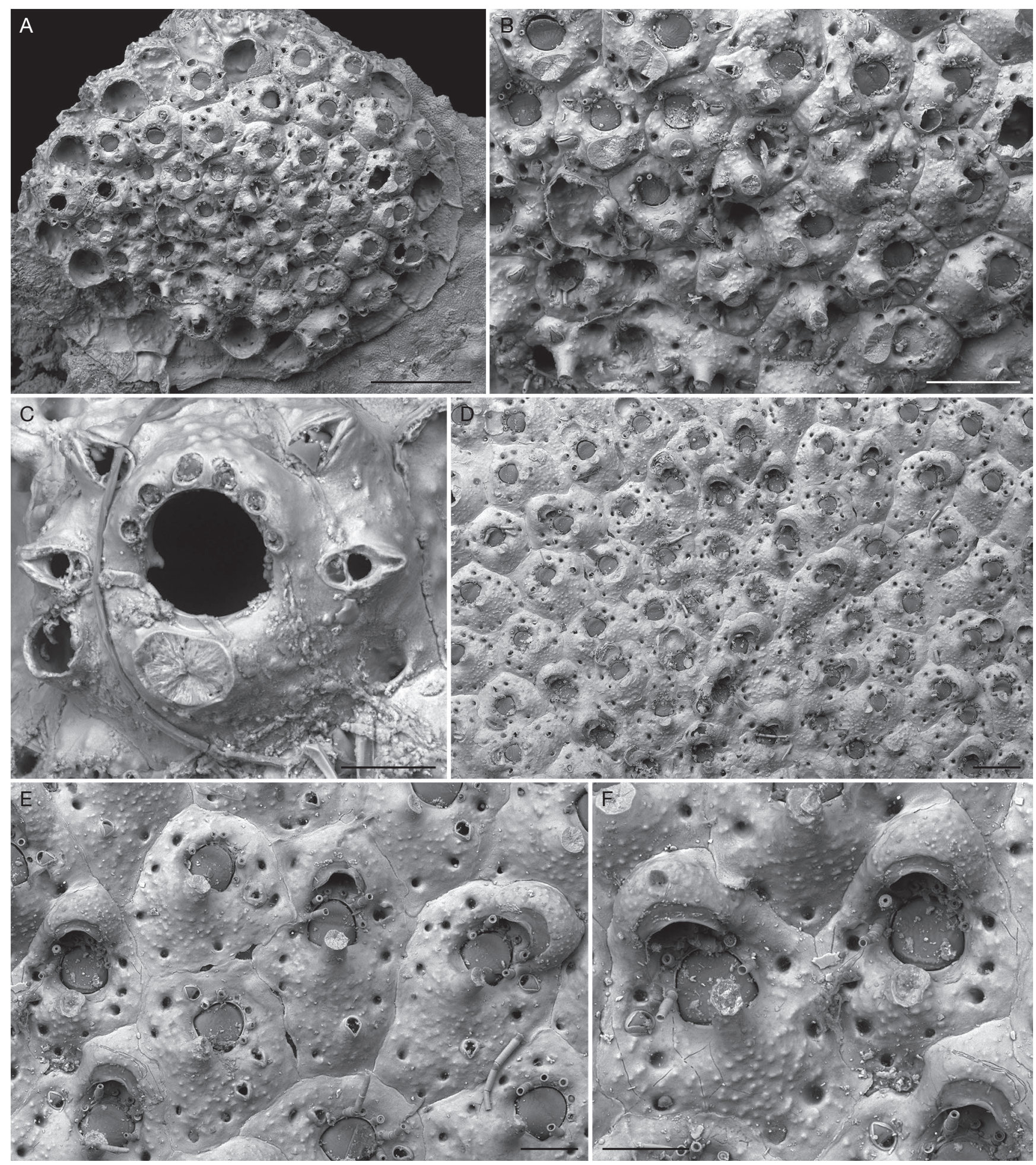

FIG. 7. - Pleuromucrum multidentatum (Thornerly, 1905) n. comb. A-C, lectotype NHMUK 1906.12.3.4, Recent, Ceylon. A, general view of the colony; B, group of zooids; C, close-up of an autozooid showing six oral spine bases, orificial condyles, stout broken-off suboral mucro and multiple adventitious avicularia budded from marginal areolar pores. D-F, syntype, NHMUK 1975.7.28.24, Recent, Ceylon. D, general view of the colony; E, group of autozooids and ovicellate zooids; F, close-up of two ovicellate zooids. Scale bars: A, $500 \mu \mathrm{m} ; \mathrm{B}, \mathrm{C}, \mathrm{D}, 200 \mu \mathrm{m} ; \mathrm{E}, \mathrm{F}, 100 \mu \mathrm{m}$.

Allorhynchozoon Liu in Liu, Yin \& Ma, 2001 is a junior subjective synonym of Lifuella (http://bryozoa.net by P. Bock, accessed 10.I.2017) and therefore also of Pleuromucrum. The type species of Hippoporella, H. hippopus, dif- fers from the type species of Pleuromucrum, P. saucatsense, in the ovicell originating from the distal zooid and in the presence of distinct basal pore-chambers (not obvious in Pleuromucrum). 

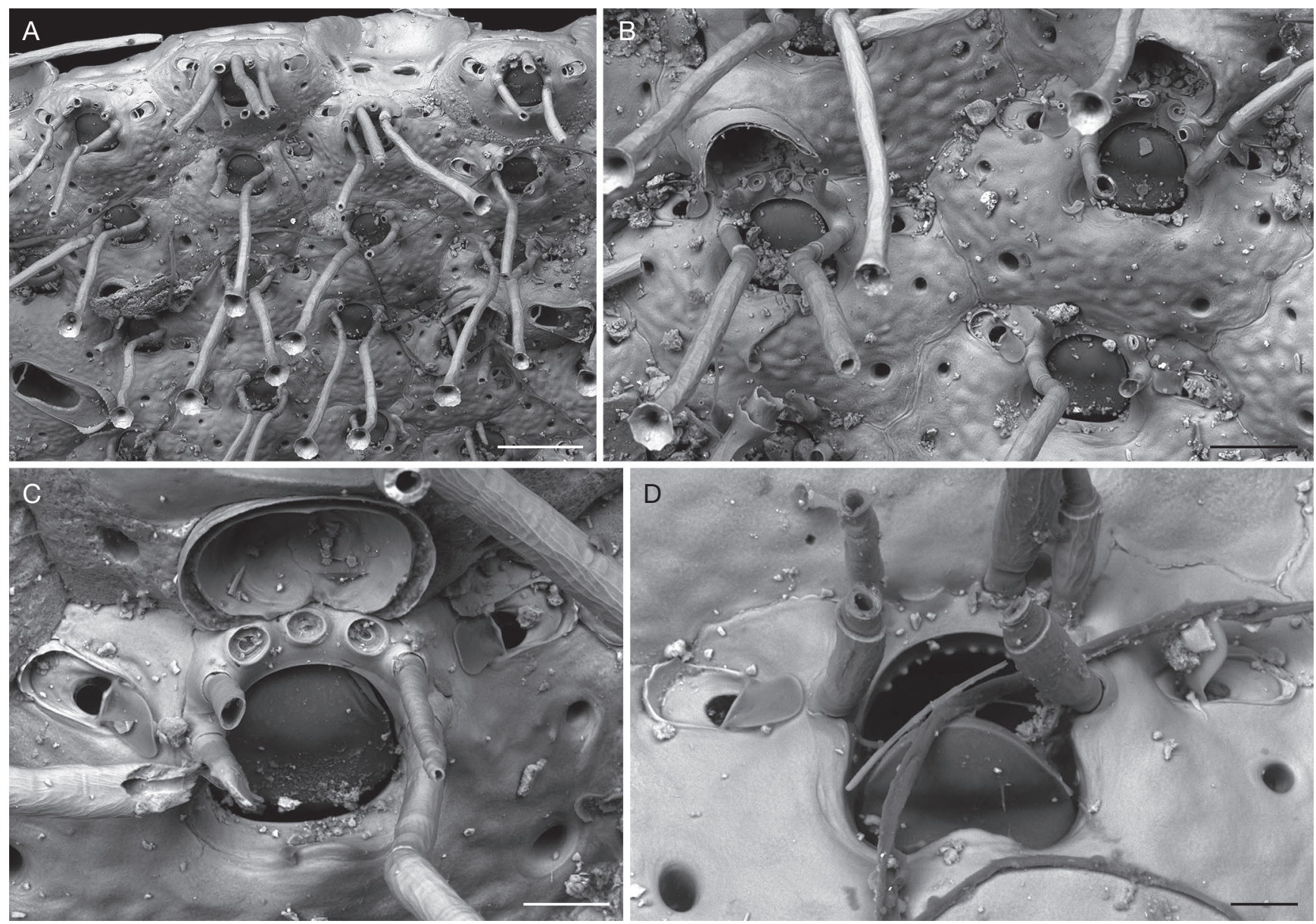

FIG. 8. - Fodinella articulata (Philipps, 1900) n. comb., syntypes NHMUK 1999.3.9.7a, b, Recent, Lifu, Loyalty Island, Sandal Bay. A, group of zooids; B, two ovicellate zooids; C, close-up of the distal part of a zooid showing the ovicell in formation, seven spine bases and the distolateral avicularia with serrated rostrum tips; D, close-up of an orifice showing the beaded anter and proximal mucro. Scale bars: A, $200 \mu \mathrm{m} ; \mathrm{B}, 100 \mu \mathrm{m} ; \mathrm{C}, 50 \mu \mathrm{m} ; \mathrm{D}, 30 \mu \mathrm{m}$.

Of the seven species currently included in Lifuella, we are able to reassign two $-L$. multidentata (Thornely, 1905) and L. gorgonensis (Hastings, 1930) (see Di Martino et al. 2017) - to Pleuromucrum based on the re-examination of the type material, while a further three can be transferred to Pleuromucrum based on SEM images published in the literature: L. porelliformis (Kirkpatrick, 1888) sensu Tilbrook et al. (2001: 96, fig. 20C), L. lepralielloida (Pleuromucrum lepralielloidum n. comb.; Liu in Liu et al. 2001: pl. 80, figs 1-3) and L. granulata (Pleuromucrum granulatum n. comb.; Liu in Liu et al. 2001: pl. 80, figs 4-6). Re-examination of the type material of Lifuella articulata (Fodinella articulata n. comb.; Philipps 1900) revealed a beaded anter (Fig. 8) typical of Fodinella, to which it is here reassigned. Lepraliella moorabolensis (MacGillivray, 1895) sensu Gordon (1984) was tentatively placed in Lifuella by Tilbrook et al. (2001). Based on Gordon's (1984: 123) description the anter of this species as "smoothly rounded distally with no beading", this species fits within the diagnosis of Pleuromucrum. However, the specimen figured by (Gordon 1984: pl. 50, fig. D) shows small oval adventitious avicularia with serrated rostrum tips more typical of species of Fodinella. Restudy of the type material of $L$. mooraboolensis is needed to ascertain whether this fossil Australian species is conspecific with the Recent New Zealand species, and into which genus it should be referred.

Two further fossil species of Pleuromucrum were found in the early Miocene Chipola Formation of Florida (Di Martino et al. 2017).

\section{Pleuromucrum saucatsense Vigneaux, 1949}

(Fig. 9)

Material eXamined. - Figured syntypes (Vigneaux 1949: 105, pl. 10, figs 6, 7), C.B.317-1 and C.B.318-2. C.B.318-2 is here designated as the lectotype of the species.

TyPe LOCALITY. — Saucats, Pont-Pourquey, Gironde, Aquitaine, France.

AgE. - Burdigalian, early Miocene.

\section{DESCRIPTION}

Colony encrusting, multiserial, unilaminar (Fig. 9A). Autozooids distinct, delineated by narrow interzooidal furrows, quincuncially arranged, hexagonal, longer than wide (mean L/W 1.45). Frontal shield convex, granular, imperforate except for a single row of subcircular to elliptical, marginal areolar 

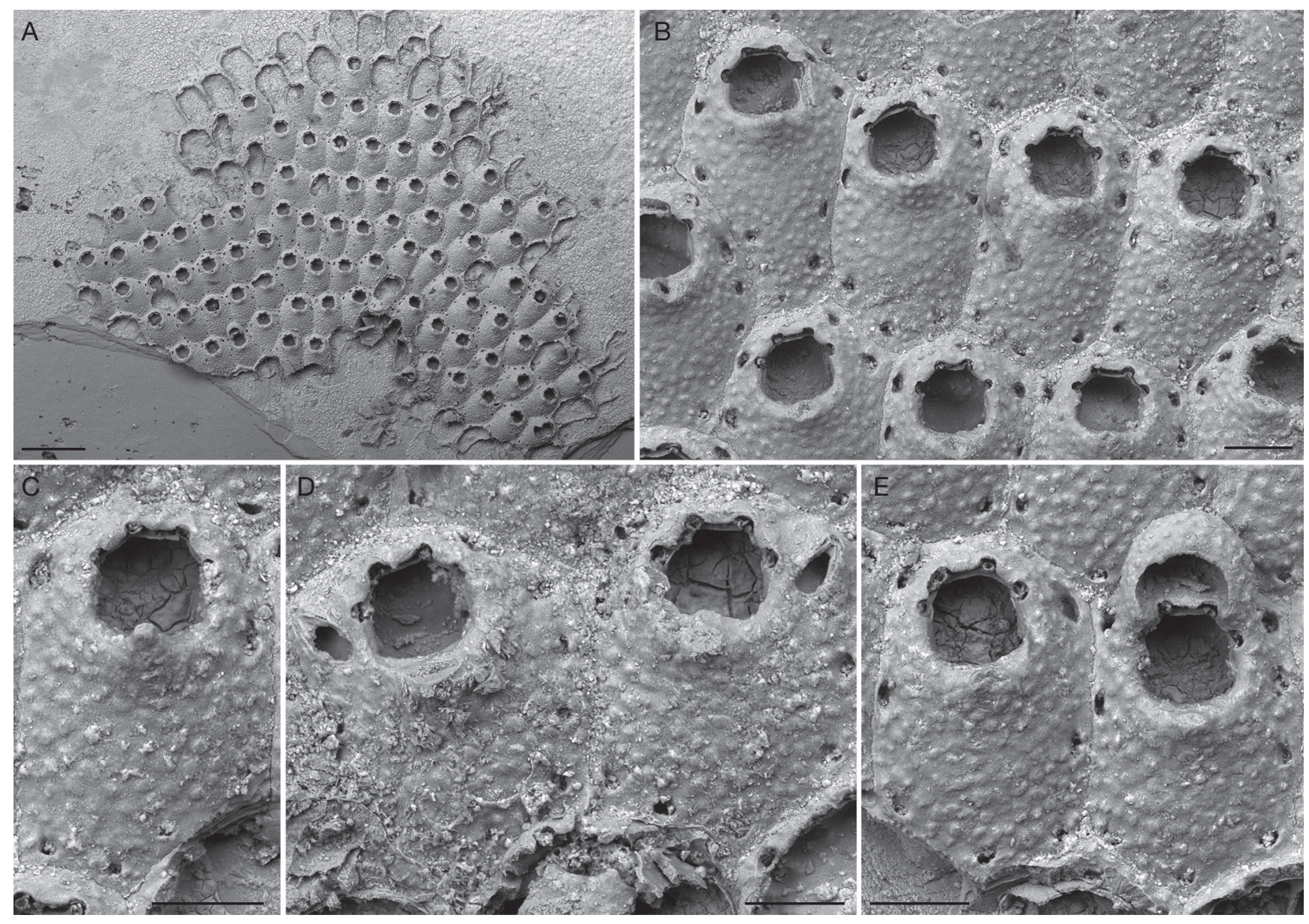

FIG. 9. - Pleuromucrum saucatsense Vigneaux, 1949, figured syntype C.B.318-2, Burdigalian, early Miocene, Saucats, Pont-Pourquey, Gironde, Aquitaine, France. A, general view of the colony; B, group of autozooids; C, close-up of an autozooid showing the suboral mucro; D, two autozooids with adventitious avicularia; E, close-up of an autozooid and an ovicellate zooid. Scale bars: A, $500 \mu \mathrm{m}$; B, C, D, E, $100 \mu \mathrm{m}$.

pores, 15-25 $\mu \mathrm{m}$ long (Fig. 9B). Orifice bell-shaped, almost equidimensional (Fig. 9C, D); four distal oral spine bases in both ovicellate and non-ovicellate zooids, about $10 \mu \mathrm{m}$ in diameter (Fig. 9C, D). Suboral mucro conical with a rounded tip (Fig. 9C). Adventitious avicularia single or absent, laterooral, rounded triangular, distolaterally directed (Fig. 9D); crossbar not observed. Ovicells subimmersed, with the same granular appearance as the frontal shield, imperforate, with a widely arched opening (Fig. 9E).

\section{MEASUREMENTS}

ZL $368 \pm 34,308-435$ (20); ZW $254 \pm 29,211-319$ (20); OL $85 \pm$ 4, 79-82 (20); OW $105 \pm$ 4, 103-108 (20); OvL $105 \pm$ 4, 103-108 (2); OvW $133 \pm 11,126-141$ (2); AvL $72 \pm 8$, 66-78 (2); AvW $37 \pm 2,36-39$ (2).

\section{REMARKS}

In the two type specimens available for study we observed only two avicularia, both lacking a pivotal bar, which may be a preservational artifact rather than a genuine absence. As the presence of a single latero-oral avicularium may be related to the age of the colony, we cannot exclude the possibility that older colonies of this species could develop paired latero-oral avicularia, as well as other avicularia sparse on the frontal shield and budded from marginal areolar pores, as observed for other species of the genus. Pleuromucrum saucatsense differs from P. multidentatum (Thornely, 1905) n. comb. in having four oral spine bases instead of six, a bell-shaped orifice without well defined condyles, and a slender and shorter suboral mucro. Furthermore, zooids in P. multidentatum n. comb. are generally smaller (ZL $298 \pm 50$, 209-389 [20]; ZW $274 \pm 41$, 202-341 [20]), although highly variable in size, and with a lower mean ratio L/W (1.09 vs 1.45$)$ than those of P. saucatsense. Among other species here assigned to Pleuromucrum, $P$. gorgonensis (Hastings, 1930) n. comb. and $P$. porelliformis (Kirkpatrick, 1888) n. comb. differ in having two and eight oral spine bases respectively. P. gorgonensis $\mathrm{n}$. comb. also differs in having a trifid suboral mucro and elongate adventitious avicularia. Pleuromucrum porelliformis n. comb. is characterised by a finely serrated lip on the distal edge of the suboral mucro.

\section{DISCUSSION}

Restudy of the long-neglected bryozoans described by Vigneaux (1949) from the Miocene of Aquitaine, France, has focused on 
type specimens of the type species of five cheilostome genera introduced in this work. Application of SEM has allowed the identities of Hemiphylactella, Pleuromucrum, Stephanollina, Schizosmittina and Hemicosciniopsis to be clarified for the first time. Whereas Schizosmittina has been used as a repository for several Eocene-Recent bryozoan species, the other genera have been largely forgotten, to some extent because their identities could not be clearly understood from Vigneaux's descriptions and figures. None of Vigneaux's genera can be considered as junior synonyms of earlier genera and all have taxonomic utility. One genus - Pleuromucrum - is interpreted as an objective senior synonym of Lifuella Gordon \& d'Hondt, 1997 and Allorhynchozoon Liu in Liu, Yin \& Ma, 2001.

Further studies are required of the Vigneaux and other collections from the Miocene of Aquitaine to elucidate the taxonomy and stratigraphical distributions of bryozoans from a region containing the historical stratotypes of two Miocene stages, the Aquitanian and the Burdigalian.

\section{Acknowledgements}

We thank Bruno Cahuzac (UFR Science de la Terre et de la Mer, Université de Bordeaux) for arranging the loan of the type specimens of M. Vigneaux collection, Mary Spencer Jones (NHMUK) for making available type specimens of Recent species for study, Mike Smith (NHMUK) for helping with the logistics, and Dennis Gordon (NIWA) for helpful taxonomic advice. Christine Strullu Derrien (NHMUK) helped with the French version of the abstract. This work was supported by a Leverhulme Trust Research Project Grant (Grant number: RPG-2015-036). Finally, we thank Dennis Gordon and Pierre Moissette, who read a previous version of the manuscript.

\section{REFERENCES}

BASSLER R. S. 1935. - Bryozoa. Generum et Genotyporum. Index et Bibliographica, in QuenstedT W. (ed.), Fossilium Catalogus I. Animalia. Volume 67. W. Junk, s'Gravenhage, 229 p.

Brown D. A. 1952. - The Tertiary Cheilostomatous Polyzoa of New Zealand. Trustees of the British Museum (Natural History), London, $405 \mathrm{p}$.

BUSK G. 1884. - Report on the Polyzoa collected by H.M.S. Challenger during the years 1873-1876. Part 1. The Cheilostomata. Report on the Scientific Results of the Voyage of the H.M.S. "Challenger". Zoology, Volume 10, 216 p.

CANU F. 1917. - Les bryozoaires fossiles des terrains du SW de la France. XI. Rupélien. Bulletin de la Société géologique de France, série 4, 17:350-361. https://biodiversitylibrary.org/page/30968007

CANu F. \& BASSLER R. S. 1923. - North American later Tertiary and Quaternary Bryozoa. United States National Museum Bulletin 125: 1-302. https://biodiversitylibrary.org/page/7904193

CANU F. \& BASSLER R. S. 1927. - Classification of the cheilostomatous Bryozoa. Proceedings of the United States National Museum 69: 1-42. https://doi.org/10.5479/si.00963801.69-2640.1

Cheetham A. H. 1963. - Late Eocene zoogeography of the eastern Gulf Coast region. Memoirs of the Geological Society of America 91: 1-113.

Di Martino E., Taylor P. D. \& Portell R. W. 2017. — Bryozoans from the lower Miocene Chipola Formation, Calhoun County, Florida, USA. Bulletin of the Florida Museum of Natural History 53: 97-200.
Florence W. K., Hayward P. J. \& Gibbons M. J. 2007. — Taxonomy of shallow-water Bryozoa from the west coast of South Africa. African Natural History 3: 1-58. https://hdl.handle. net/10520/EJC17350

GORDON D. P. 1984. — The marine fauna of New Zealand: Bryozoa Gymnolaemata from the Kermadec Ridge. New Zealand Oceanographic Institute Memoirs 91: 1-198.

GordON D. P. 1989. — The marine fauna of New Zealand: Bryozoa: Gymnolaemata (Cheilostomida Ascophorina) from the western south Island continental shelf and slope. New Zealand Oceanographic Institute Memoirs 97: 1-158.

GORDON D. P. 1994. - Tertiary bryozoan genera in the presentday Australasian fauna - Implications for classification and biogeography. Invertebrate Taxonomy 8: 283-298. https://doi. org/10.1071/IT9940283

GORDON D. P. 2006. - Sfeniella, nom. nov. pro Sphenella Duvergier 1924 , and Sfeniellidae, a new family of umbonuloid-shielded cheilostomes. Courier Forschungsinstitut Senckenberg 257: 65-72.

Gordon D. P. \& D'HondT J.-L. 1997. - Bryozoa: Lepraliomorpha and other Ascophorina from New Caledonian waters, in Crosnier A. (ed.), Résultats des Campagnes MUSORSTOM, volume 18. Mémoires du Muséum national d'Histoire naturelle, Paris 176: 9-124.

GraY J. E. 1848. - List of the Specimens of British Animals in the Collection of the British Museum. Part 1. Centrionae or Radiated Animals. Trustees of the British Museum, London, $173 \mathrm{p}$.

Hastings A. B. 1930. - Cheilostomatous Polyzoa from the vicinity of the Panama Canal collected by Dr. C. Crossland on the cruise of the S. Y. 'St. George'. Proceedings of the Zoological Society, London 47: 697-740. https://doi.org/10.1111/j.1096-3642.1929.tb01453.x

HiNCKS T. 1879. - On the classification of the British Polyzoa. Annals and Magazine of Natural History, Series 5, 3: 153-164. https://biodiversitylibrary.org/page/25159184

HiNCKS T. 1883. - Contribution towards a general history of the marine Polyzoa. XI. Foreign Cheilostomata (Miscellaneous). Annals and Magazine of Natural History, Series 5, 11: 193-202. https://biodiversitylibrary.org/page/29222109

Jullien J. 1888. — Bryozoaires. Mission scientifique du Cap Horn, 1882-83, vol. 6: 1-92. https://biodiversitylibrary.org/page/5215910

KirkPATrick R. 1888. - Polyzoa from Port Phillip. Annals and Magazine of Natural History, Series 6, 2: 12-21. https://biodiversitylibrary.org/page/25123041

LiU X., Yin X. \& MA J. 2001. - Biology of Marine-Fouling Bryozoans in the Coastal Waters of China. Science Press, Beijing, 860 p.

MacGillivray P. H. 1879. - Polyzoa, in McCoy F. (ed.), Prodromus of the Zoology of Victoria. Volume 1. Decade 4. Government Printer, Melbourne: 15-40. https://biodiversitylibrary.org/page/5221188

MacGillivray P. H. 1895. - A monograph of the Tertiary Polyzoa of Victoria. Transactions of the Royal Society, Victoria 4: 1-166. https://doi.org/10.5962/bhl.title.6076

PHILIPPS E. G. 1900. — Report on the Polyzoa collected by Dr Willey from the Loyalty Isles, New Guinea and New Britain, in WILLEY A. (ed.), Zoological Results Based on Material from New Britain, New Guinea, Loyalty Islands and Elesewhere, Collected During the Years 1895, 1896 and 1897. Part 4. University Press, Cambridge: 439-450. https://biodiversitylibrary.org/page/21340255

SMITT F. A. 1868. - Kritisk förteckning öfver Skandinaviens Hafs-Bryozoer. IV. Ofversigt af Kongliga Vetenskaps-Akademiens förhandlingar 25: 3-230.

Soule D. F., Soule J. D. \& Chaney H. W. 1995. - Taxonomic Atlas of the Benthic Fauna of the Santa Maria Basin and Western Santa Barbara Channel. The Bryozoa. Irene McCulloch Foundation Monograph Series, Number 2. Hancock Insitute of Marine Studies, University of Southern California, Los Angeles, $344 \mathrm{p}$.

Thornely L. R. 1905. - Report on the Polyzoa Collected by Professor Herdmann, at Ceylon, in 1902. Report to the Government of Ceylon on the Pearl Oyster Fisheries of the Gulf of Manar, Part 4: 107-130. 
TilbrooK K. J. 2006. - Cheilostomatous Bryozoa from the Solomon Islands. Santa Barbara Museum of Natural History, Monographs 4 (Studies in Biodiversity Number 3), 386 p.

Tilbrook K. J., Hayward P. J. \& Gordon D. P. 2001. - Cheilostomatous Bryozoa from Vanuatu. Zoological Journal of the Linnean Society 131: 35-109. https://doi.org/10.1111/j.1096-3642.2001.tb01309.x UtTley G. H. \& BullivanT J. S. 1972. - Biological results of the
Chatham Islands 1954 Expedition. Part 7. Bryozoa Cheilostomata. New Zealand Oceanographic Institute Memoirs 57: 1-61.

VignEAUX M. 1949. — Révision des bryozoaires néogènes du Bassin d'Aquitaine et essai de classification. Mémoires de la Société géologique de France 60: 1-155.

ZÁGORŠEK K. \& KÁZMÉR M. 2001. — Eocene Bryozoa from Hungary. Courier Forschungsinstitut Senckenberg 231: 1-159.

Submitted on 13 January 2017:

accepted on $21^{\text {st }}$ March 2017; published on 29 December 2017. 